\title{
DYNAMICS OF THE FOLLICULAR DEVELOPMENT DURING PRID TREATMENT AND QUALITY OF THE FOLLOWING SEXUAL CYCLE IN POSTPARTUM COWS
}

\author{
R. DOLEŽEL \\ Clinic of Obstetrics, Gynaecology and Andrology, Faculty of Veterinary Medicine, University of Veterinary \\ and Pharmaceutical Sciences, 61242 Brno
}

Received January 5, 1995

Accepted May 30, 1995

\begin{abstract}
D o l e ž e 1 R.: Dynamics of the Follicular Development During PRID Treatment and Quality of the Following Sexual Cycle in Postpartum Cows. Acta vet. Brno 1995, 64:187-194.

Ten postpartum cows (Bohemian Pied Cattle) were treated by progesterone intravaginal device (PRID) for 10 days. Four untreated cows served as the control group. Transrectal ultrasonographical examination and sampling of milk and peripheral blood for milk progesterone and plasma estradiol assay were performed at 3 and 4 alternating intervals from the day 510 post partum to the 2nd postpartum ovulation. Follicles persisted during PRID treatment. Dominant follicles slowly grew and ovulated on the day $3 \pm 0.63$ after progesterone treatment in cows with follicular dominance at the term of PRID insertion and they ovulated on the day $5.3 \pm 1.26$ in cows without follicular dominance before PRID. Concentration of the plasma estradiol (42.9 \pm $20.65 \mathrm{pg} / \mathrm{ml})$ varied and concentration of the milk progesterone $(0.8 \pm 1.18 \mathrm{ng} / \mathrm{ml})$ after the initial increase decreased during PRID treatment. Two and three follicular waves occurred before the 1 st postpartum ovulation and during the 1 st postpartum sexual cycle in the control cows. Concentration of plasma estradiol increased in relation with growth of the dominant follicles and the particular peaks gradually increased from parturition to the 2 nd ovulation. Low concentration of the milk progesterone temporarily increased during the 1st postpartum sexual cycle. We found the term of the 1st postpartum ovulation, the length of the 1st postpartum sexual cycle and the number of follicular waves during the sexual cycle in PRID treated cows and untreated cows $29.3 \pm 3.89: 23.8 \pm 5.19$ day post partum, $19.8 \pm 2.44: 19.3 \pm 1.71$ days and $2.3 \pm 0.48: 2.5 \pm 0.58$ respectively.
\end{abstract}

Dominant follicle, follicular wave, postpartum ovulation, postpartum sexual cycle, plasma estradiol, milk progesterone

Progestagen treatment for several days (5-20 days) is one of the most successful methods of the estrus induction during anestrus period or the estrus synchronization during sexual cycle in animals. The progestagen treatment induces estrus with higher levels of the plasma estradiol and more expressive LH peak compared to the 1st spontaneous estrus and longer the 1st sexual cycle with higher levels of the milk or plasma progesterone and lower levels of 13,14 dihydro-15-ketoprostaglandin F2alpha (PGFM) compared to the 1st spontaneous sexual cycle in postpartum cows ( $\mathrm{T} \mathrm{r}$ o x e l and $\mathrm{K} \mathrm{e} s \mathrm{l}$ e r 1984; $\mathrm{R} \mathrm{u} \mathrm{t} t \mathrm{er}$ et al. 1985; G a r c i a-W ind e r et al. 1987; $\mathrm{S} \mathrm{m}$ i th et al. 1987; M e e et al. 1991). Our previous work (D o l e ž e l et al. 1993b) showed slow growth of the dominant ovarian follicles and stagnation of the subordinate follicles during 10 days progesterone intravaginal device application in early postpartum cows. The dominant follicles ovulated on the day 3 and 4 after progesterone treatment in cows with morphological follicular dominance at the term of progesterone intravaginal device insertion. Ovulation occurred later in cows without morphological follicular dominance before progesterone treatment.

The purpose of the present experiment is to confirm our preliminary results and evaluation of quality of the follicular population using plasma estradiol assay. 


\section{Materials and Methods}

Fifteen postpartum cows (Bohemian Pied Cattle) were used in the experiment. The milking cows were housed on a maize silage/ grass hay/ concentrates diet. Ten cows were treated by progesterone intravaginal devices (PRID-CEVA, France) containing a total of $1.55 \mathrm{~g}$ progesterone and $10 \mathrm{mg}$ oestradiol benzoate from day $15-20$ to day 25-30 post partum. Five untreated cows represented the control group. One of the control cows was excluded before the end of the experiment for the reason of ovarian cysts.

Transrectal ultrasonographical examination (linear $5 \mathrm{MHz}$ probe and scanner V 500, Alloca; video copy processor P66E, Mitsubishi) were performed at 3 and 4 day alternating intervals from day 5-10 post partum to the 2nd postpartum ovulation. Ovarian structures (follicles $>3 \mathrm{~mm}$, corpora lutea) were individually identified by reference to their position and diameter in sequential image. The day after estrus was determined as the term of ovulation. If estrus was not observed the time between occurrence and disappearance of the largest follicle followed by formation of a CL was determined as the term of ovulation. The samples of milk for progesterone assay were taken in the same intervals. Blood samples for plasma estradiol assay were taken from v.jugularis to glass tubes with chelaton in the intervals of clinical examination to the 1st postpartum estrus in progesterone treated cows and to the 2nd ovulation in untreated cows. The blood samples were centrifuged and plasma and milk were frozen and stored at $-20^{\circ} \mathrm{C}$ until assayed. Milk progesterone was assayed by RIA ( $\mathrm{S} \mathrm{t} \mathrm{u} \mathrm{p} \mathrm{n} \mathrm{i} \mathrm{c} \mathrm{k} \mathrm{y} \mathrm{1975)} \mathrm{and} \mathrm{plasma} \mathrm{estradiol}$ was assayed by method described by $\mathrm{P} i \mathrm{c} \mathrm{h}$ o $\mathrm{v}$ á et al.(1981) using antigen acquired by immunisation with progesterone-17-CMS-BSA.

Student's $\mathrm{t}$-test was used for statistical evaluation.

\section{Results}

None of the experimental cows was bearing corpus luteum (CL) during PRID treatment. Dominant follicles slowly grew during progesterone (pg) treatment and they ovulated on the day $3.0 \pm 0.63$ (2-4) after PRID removal in cows with morphological follicular dominance before PRID insertion $(n=6)$. Dominant follicle that occurred during $\mathrm{pg}$ treatment ovulated on the day $5.3 \pm 1.26(5-7)$ after PRID removal in cows without morphological follicular dominance before PRID insertion $(n=4)$. Number and size of the subordinate follicles

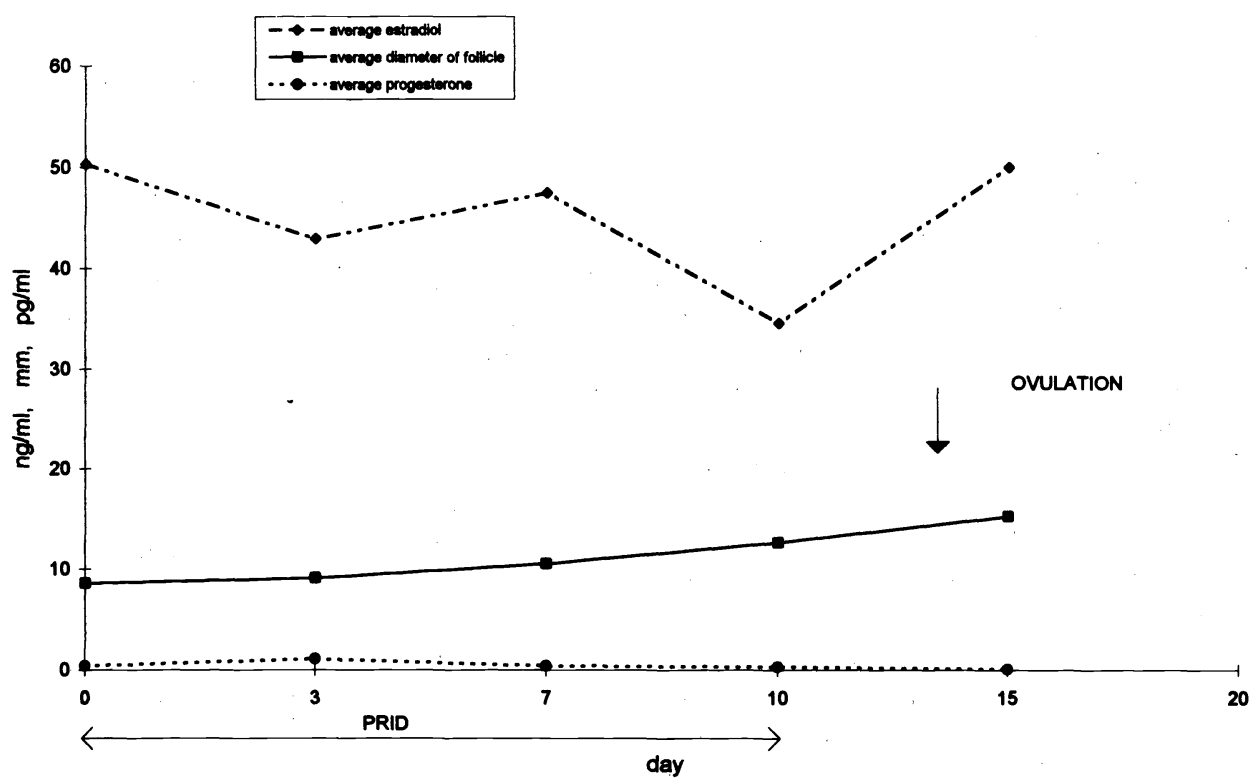

Fig. 1. Size of dominant follicles and concentrations of plasma estradiol and milk progesterone during PRID in cows. 


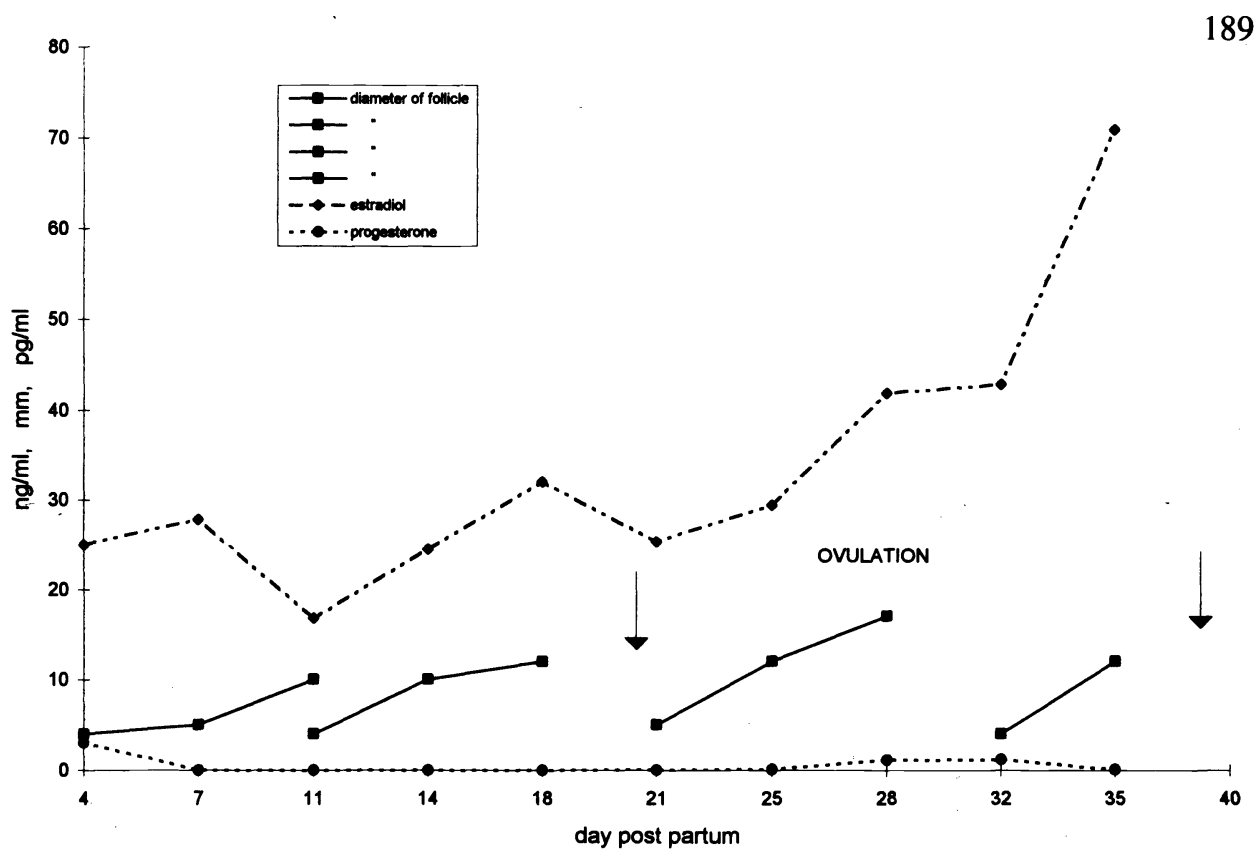

Fig. 2. Size of dominant follicles and concentrations of plasma estradiol and milk progesterone in control cow 1.

stagnated. Concentration of the plasma estradiol $(42.9 \pm 20.65 \mathrm{pg} / \mathrm{ml})$ varied during $\mathrm{pg}$ treatment and concentration of the milk progesterone $(0.8 \pm 1.18 \mathrm{ng} / \mathrm{ml})$ after the initial increase decreased (Fig. 1).

\section{Discussion}

Our results confirm the knowledge about the persistence of dominant follicles and inhibition of ovulation during exogenous progesterone $(\mathrm{pg})$ administration ( $\mathrm{R}$ o b e r t s o $\mathrm{n}$ et al. 1989; S i r o i s and F o r t u n e 1990; D o l e ž e l et al. 1993b). Persistence of the dominant follicle and stagnation of the subordinate follicles is evidence of the morphological as well as functional follicular dominance ( $\mathrm{r}$ e 1 a $\mathrm{n} \mathrm{d}$ and $\mathrm{R} \mathrm{o} \mathrm{c} \mathrm{h} \mathrm{e} \mathrm{1987;}$ F o r t u n e 1993). Precondition of the exogenous progesterone effect is the absence of endogenous progesterone since cyclicity of the follicular waves continues in the presence of corpus luteum ( $\mathrm{T}$ a y $\mathrm{l}$ o $\mathrm{r}$ et al. 1993). D u c h e $\mathrm{n} \mathrm{s}$ et al. (1994) describe dependence of the follicular development on the dose of exogenous progesterone. Likewise $\mathrm{L} \mathrm{u}$ c y et al.(1990) state negative effect of the corpus luteum on PRID induction or synchronization of estrus.

Table 1

Term of the 1st postpartum ovulation (day pp) and length of the 1st sexual cycle (days) with the number of the follicular waves in treated (PRID) and untreated cows

\begin{tabular}{|lrc|}
\hline & PRID & Control \\
\hline & & \\
1st ovulation & $29.3 \pm 3.89$ & $23.8 \pm 5.19 \mathrm{a}$ \\
1st sexual cycle & $19.8 \pm 2.44$ & $19.3 \pm 1.71$ \\
follicular waves & $2.3 \pm 0.48$ & $2.5 \pm 0.58$ \\
\hline
\end{tabular}




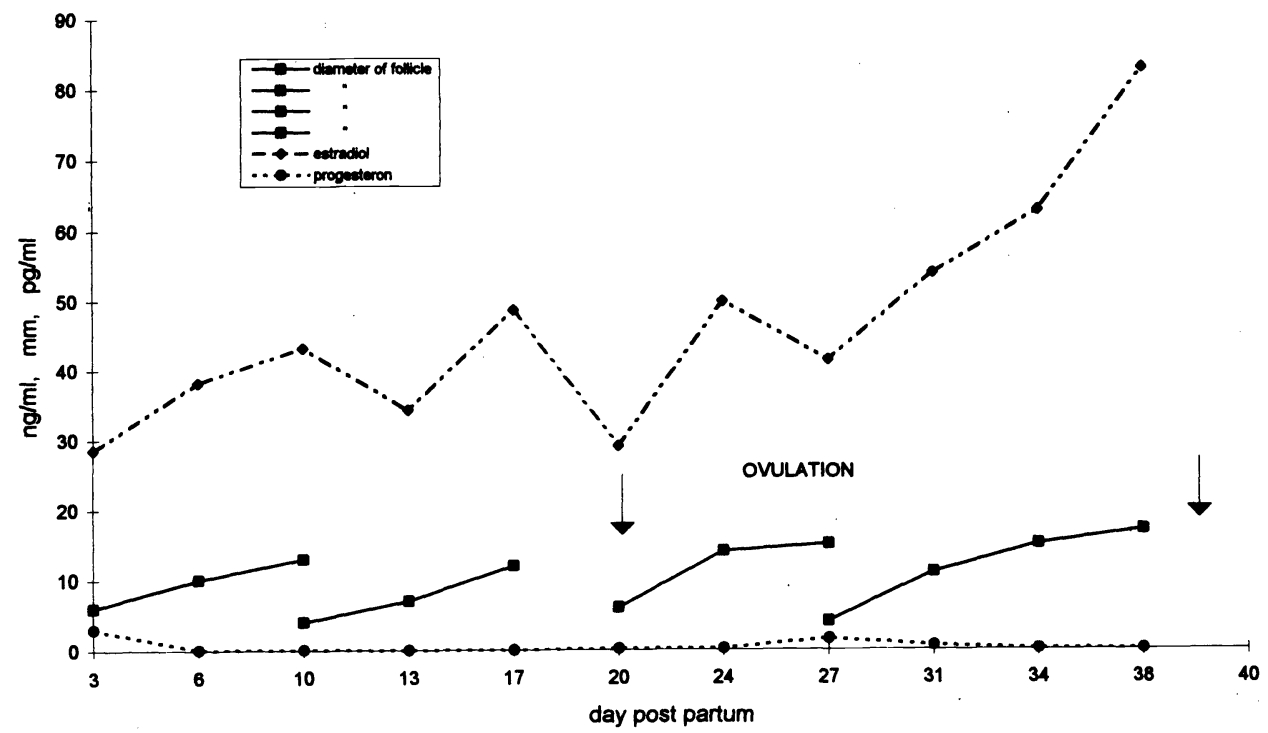

Fig. 3. Size of dominant follicles and concentrations of plasma estradiol and milk progesterone in control cow 2 .

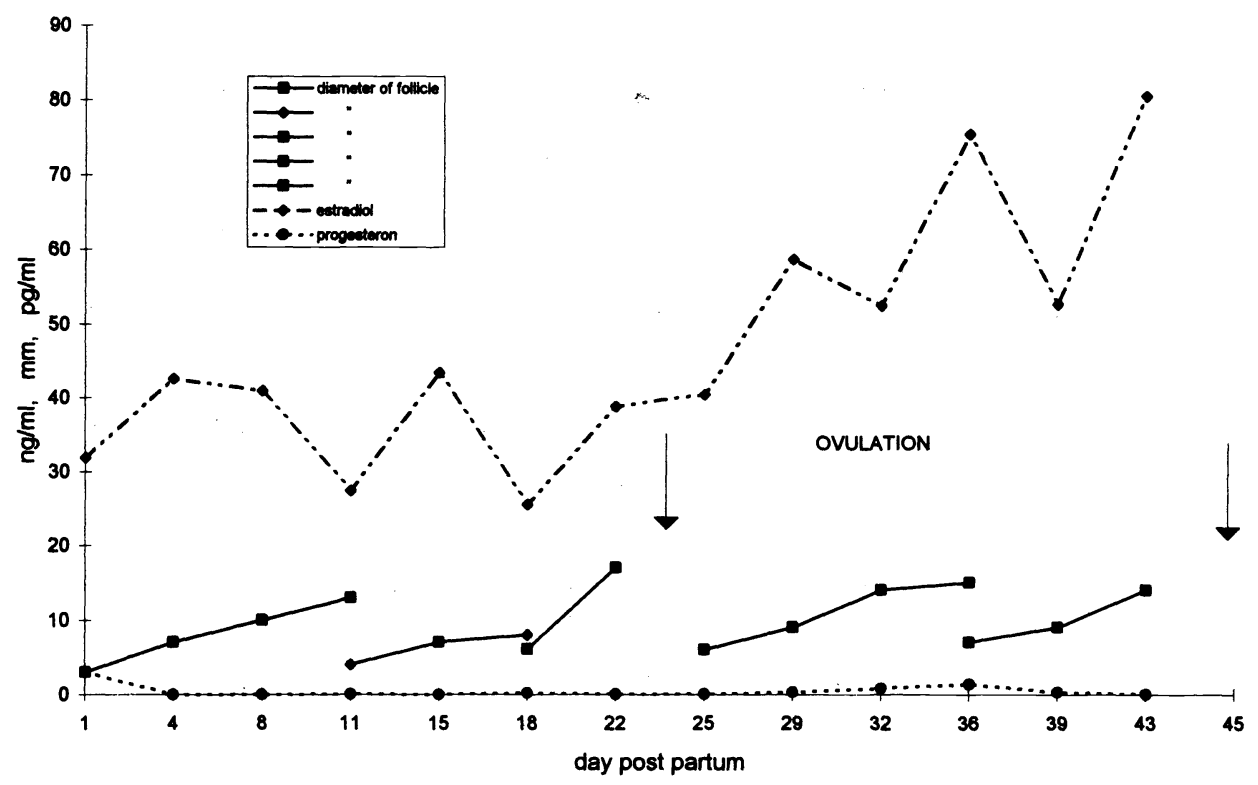

Fig. 4. Size of dominant follicles and concentrations of plasma estradiol and milk progesterone in control cow 3. 


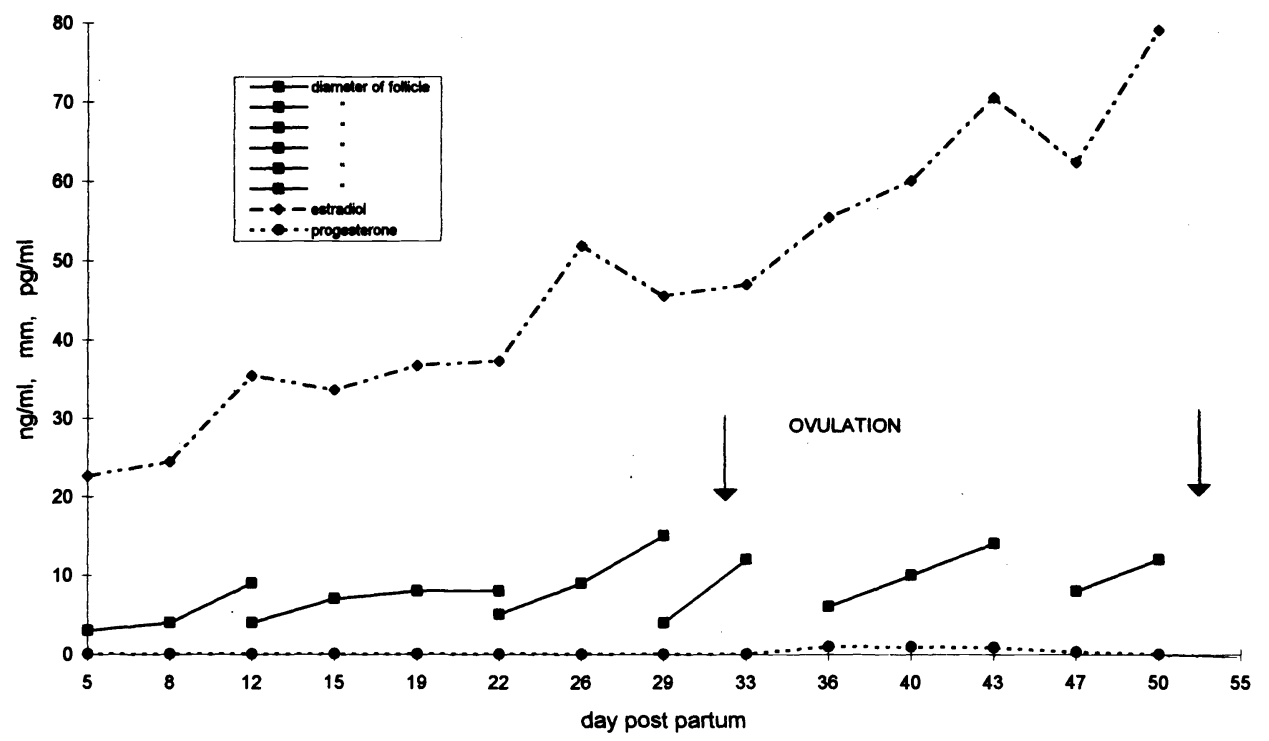

Fig. 5. Size of dominant follicles and concentrations of plasma estradiol and milk progesterone in control cow 4.

Average concentration of the plasma estradiol decreased and varied during pg treatment in our experiment. This condition may be due to its relation to stagnation of the follicular development. G a r c i a -W in d e r et al.(1987) and M e e et al.(1991) state higher secretion of estradiol in the preovulatory follicles in cows after pg treatment compared to untreated cows. Likewise we found an increase of plasma estradiol and growth of the dominant follicle after removal of intravaginal progesterone device. Nevertheless levels of plasma estradiol during and just after pg treatment were comparable with levels of estradiol before the 1st spontaneous postpartum ovulation but they were lower in comparison with the 1st spontaneous postpartum sexual cycle. Wh i t e et al. (1985) and S $\mathrm{m}$ it h (1986) state the relationship between the quality of the preovulatory follicular development and the quality of the following corpus luteum.

In spite of the average concentration of milk progesterone during pg treatment were lower then it is described by For t u ne (1993) and M a c mill a n and Pe te r s o n (1993) they were significantly higher compared to the previous values in the same cows and the values in control cows during the same postpartum period.

The average length of the sexual cycle with the number of follicular waves after $\mathrm{pg}$ treatment in our experiment almost reach the characteristic values for normal sexual cycle in cows. However there were some differences between cows with and without follicular dominance at the term of PRID insertion. The former had a longer sexual cyle with a higher number of follicular waves ( $21.2 \pm 0.41$ days, $2.5 \pm 0.55$ waves) compared to the latter (17.8 \pm 2.87 days, $2.0 \pm 0.00$ waves). Even when the length of the 1 st spontaneous postpartum sexual cycle is influenced by the term of the previous ovulation it is generally shorter than following sexual cycles (M o r r o w et al. 1966; Edgert on and $\mathrm{H}$ af s 1973; S c h a m s 
et al. 1978; $D$ u b y et al. 1985; $R$ u t $t$ e $r$ and $R$ a n d e 1 1985). In our experiment the 1 st spontaneous postpartum sexual cycle in control cows (except one cow) was comparable to the sexual cycle after pg treatment. The term of the 1st spontaneous ovulation was probably the cause of the similarity of the 1st sexual cycle in control cows to the sexual cycle after PRID treatment as well as to the characteristic values for the later sexual cycles in cows. In the previous work (D o l e ž e l et.al. 1993a) we observed a shorter 1st spontaneous sexual cycle with a lower number of the follicular waves after the ovulation which occurred before day 20 post partum as compared to the cows that ovulated later.

\section{Dynamika folikulárního vývoje během ošetření PRID a kvalita následujícího pohlavního cyklu u krav v poporodním období}

Deset krav plemene Český strakatý skot v poporodním období bylo ošetřeno intravaginálními progesteronovými tělísky (PRID) po dobu 10 dnů. Čtyři neošetřené krávy tvořily kontrolní skupinu. Ve 3 a 4 denních intervalech od 5.-10. dne po porodu do 2. poporodní ovulace bylo u krav prováděno transrektální ultrazvukové vyšetření a odběry mléka i periferní krve ke stanovení progesteronu v mléce a estradiolu v krevní plazmě. Během ošetření PRID ovariální folikuly perzistovaly. U krav s folikulární dominancí patrnou v termínu zavedení PRID dominantní folikuly pomalu rostly a ovulovaly $\mathrm{v}$ den $3,0 \pm 0,63$ po ošetření progesteronem. U krav bez folikulární dominance před ošetřením PRID folikuly ovulovaly v den $5,3 \pm 1,26$ po ošetření. Během ošetření PRID koncentrace plazmatického estradiolu (42,9 \pm $20,65 \mathrm{pg} / \mathrm{ml})$ kolísala a koncentrace progesteronu v mléce $(0,8 \pm 1,18 \mathrm{ng} / \mathrm{ml})$ po počátečním zvýšení se snižovala. U kontrolních krav proběhly 2 a 3 folikulární vlny před 1. poporodní ovulací i během 1. poporodního pohlavního cyklu. Koncentrace plazmatického estradiolu u těchto krav se zvyšovala současně s rủstem dominantních folikulủ a jednotlivé maximální hodnoty se postupně zvyšovaly od porodu do 2. poporodní ovulace. Nízká koncentrace progesteronu v mléce dočasně se zvýšila během 1 . poporodního pohlavního cyklu. U ošetřených krav v porovnání s neošetřenými jsme zjistili hodnoty termínu 1. poporodní ovulace (den po porodu), délky 1.pohlavního cyklu (dny) a počtu folikulárních vln během tohoto pohlavního cyklu $29,3 \pm 3,89: 23,8 \pm 5,19,19,8 \pm 2,44: 19,3 \pm 1,71$ a $2,3 \pm 0,48$ : $2,5 \pm 0,58$.

\section{Acknowledgements}

This research was supported by the Clinic of Obstetrics, Gynaecology and Andrology of the Faculty of Veterinary Medicine at the University of Veterinary and Pharmaceutical Sciences in Brno. The author thank RNDr. J. Nedbálková of the University of Veterinary and Pharmaceutical Science, Brno) and MVDr J.Lidický CSc. with co-workers of the Research Institute of Feed Supplements and Veterinary Drugs, Jílové u Prahy) for radioimmunoassays.

\section{References}

DOLEŽEL R., KARLBERG K., ROPSTAD E. 1993a: Ovarian activity in ultrasound image and milk progesterone concentration in postpartum dairy cows. Acta vet. Brno 62:173-178

DOLEŽEL R., KARLBERG K., ROPSTADE. 1993b: Ultrasound observations of ovarian structures in cows during intravaginal progesterone device application and in the following sexual cycle (preliminary report). Acta vet. Brno 62:179-185

DUBY R. T., BROWNING T., CAREY D., BLACK D. L. 1985: Progesterone synthesis and histology of postpartum bovine corpora lutea. Theriogenology 23:619-630

DUCHENS M., GUSTAFSSON H., RODRIGUEZ-MARTINEZ H., FORSBERG M., EDQVIST L.E. 1994: Effect of induced suprabasal progesterone concentrations on follicular dynamics in heifers. Reprod. Dom. Anim. 29:315-325

EDGERTON L. A., HAFS H. D. 1973: Serum luteinizing hormone, prolactin, glucocorticoid and progestin in dairy cows from calving to gestation. J. Dairy Sci. 56:451-458

FORTUNE J.E. 1993: Follicular dynamics during the bovine estrous cycle. A limiting factor in improvement of fertility? Anim. Reprod. Sci. 33:111-125 
GARCIA-WINDER M., LEWIS P. E., TOWNSEND E. C., INSKEEP E. K. 1987: Effects of norgestomet on follicular development in postpartum beef cows. J. Anim. Sci. 64:1099-1109

IRELAND J. J., ROCHE J. F. 1987: Hypothesis regarding development of dominant follicles during a bovine estrous cycle. In: Roche J. F. O'Cakkaghan D, (eds). Follicular Growth and Ovulation Rate in Farm Animals, Martinus Nijhoff Publishers, Hague: pp. 1-18.

LUCY M. C., THATCHER W. W., MACMILLAN K. L. 1990: Ultrasonic identification of follicular populations and return to estrus in early postpartum dairy cows given intravaginal progesterone for 15 days. Theriogenology 34:325-340

MACMILLAN K. L., PETERSON A. J. 1993: A new intravaginal progesterone releasing device for cattle (CIDRB) for oestrous sychronization, increasing pregnacy rates and the treatment of postpartum anoestrus. Anim. Reprod. Sci. 33:1-25

MEE M. O., STEVENSON J. S., MINTON J. E. 1991: First postpartum luteal function in dairy cows after ovulation induced by progestogen and gonadotropin-releasing hormone. J. Dairy Sci. 74:1573-1581

MORROW D. A., ROBERTS S. J., MCENTEE K. 1966: Postpartum ovarian activity and uterine involution in dairy cattle. J. Amer. Vet. Med. Ass. 149:1596-1609

PÍCHOVÁ D., PÍCHA J., ŠEVČ́́K B. 1981: Endokrinní profil po aplikaci prostaglandinu a jeho analogů. Biol. Chem. Vet. 17:157-169

ROBERSON M. S., WOLFE M. W., STUMPF T. T., KITTOK R. J., KINDER J. E. 1989: Luteinizing hormone secretion and corpus luteum function in cows receiving two levels of progesterone. Biol. Reprod. 41:997-1003

RUTTER L. M., CARRUTHERS T. D., MANNS J. G. 1985: The postpartum induced corpus luteum: functional differences from that of cycling cows and the effects of progesterone pretreatment. Biol. Reprod. 33:560-569

RUTTER L. M., RANDEL R. D. 1985: Luteal competency during the resumption of ovarian cyclicity in postpartum Brahman cows. Theriogenology 5:713-725

SCHAMS D., SCHALLENBERGERE., MENZER C., STANGL J., ZOTTMEIER K., HOFFMANN B., KARG H. 1978: Profiles of LH, FSH, and progesterone in postpartum dairy cows and their relationship to the commencement of cyclic functions. Theriogenology 10:453-468

SIROIS J., FORTUNE J. E. 1990: Lengthening the bovine estrous cycle with low levels of exogenous progesterone: a model for studying ovarian follicular dominance. Endocrinology 127:916-925

SMITH M. F. 1986: Recent advances in corpus luteum physiology. J. Dairy Sci. 69:911-926

SMITH V. G., CHENAULT J. R., McALLISTER J. F., LAUDERDALE, J. W. 1987: Response of pastpartum beef cows to exogenous progestogens and gonadotropin releasing hormone. J. Anim. Sci. 64:540-551

STUPNICKI R. 1975: Direct radioimmunoassay of progesterone in plasma of farm animals. Endocrinology 66:145-151

TAYLOR C., RAJAMAHENDRAN R., WALTON J. S. 1993: Ovarian follicular dynamics and plazma luteinizing hormone concentrations in norgestomet-treatment heifers. Anim. Reprod. Sci. 32:173-184

TROXEL T. R., KESLER D. J. 1984: The effect of progestin and GnRH treatment on ovarian function and reproductive hormone secretions of anestrous postpartum suckkled beef cows. Theriogenology 21:699-711

WHITE L. M., KEISLER D. H., DAILEY R. A., INSKEEP E. K. 1985: Characterization of preovulatory follicles destined to form "subfunctional" corpora lutea. Biol. Reprod. (Suppl. 1.) 32:43-56 